\title{
Peningkatan Hasil Belajar Siswa dengan Menggunakan Alat Peraga IPA Kelas III MI Islamiyah Kudus
}

\author{
Mahfud ${ }^{1}$, Mahfud Nahrowi ${ }^{2}$ \\ ${ }^{1}$ Mahasiswa Pasca Sarjana PGMI, IAIN Salatiga Jl.Lingkar Salatiga Indonesia, \\ ${ }^{2}$ Alumni STAIN Kudus, Anggota Forkapisa IAIN Salatiga, \\ mahfudkudus2@gmail.com ${ }^{1}$
}

\begin{abstract}
Abstrak
Rendahnya hasil belajar siswa kelas III di Madrasah Ibtidaiyah (MI) Islamiyah Golantepus Kecamatan Mejobo Kudus disebabkan kurangnya keterlibatan siswadan guru secara langsung baik di dalam kelas maupun di luar kelas dalam proses pembelajaran. Untuk mengatasi masalah tersebut, perlu dilakukan Penelitian Tindakan Kelas (PTK) melalui penggunaan alat peraga Ilmu Pengetahuan Alam (IPA). Tujuan penelitian ini adalah untuk meningkatkan hasil belajar siswa dengan menggunakan alat peraga IPA kelas III di MI Islamiyah Golantepus sehingga output hasil belajar siswa dapat tercapai. Subjek penelitian adalah siswa berjumlah 27 orang, sumber data penelitian ini diperoleh dari data kualitatif berupa data hasil observasi aktivitas guru dan siswa serta data kuantitatif berupa data tes hasil belajar siswa. Hasil perhitungan menunjukkan bahwa pada siklus I diperoleh siswa yang tuntas secara individu sebanyak 13 siswa dari 27 siswa dengan ketuntasan klasikal sebesar 36\% dan daya serap klasikal sebesar 63\%. Sedangkan hasil perhitungan menunjukkan bahwa siklus II mengalami peningkatan dengan jumlah siswa yang tuntas secara individu sebanyak 23 siswa dari 22 orang siswa yang mengikuti pembelajaran dengan persentase ketuntasan klasikal sebesar $82 \%$ dengan daya serap klasikal sebesar $85 \%$. Berdasarkan hasil perhitungan dan analisis, pembelajaran menggunakan alat perga IPA dapat meningkatkan hasil belajar siswa kelas III di MI Islamiyah Golantepus Kecamatan Mejobo Kudus.
\end{abstract}

Kata Kunci: Alat Peraga IPA, Guru, Hasil Belajar, Proses Belajar, Siswa

\begin{abstract}
The low learning outcomes of third grade students in Madrasah Ibtidaiyah (MI) Golantepus Golantepus District Mejobo Kudus due to the lack of direct involvement of students and teachers both inside and outside the classroom in the learning process. To overcome this problem, Class Action Research (PTK) needs to be done through the use of natural science teaching aids (IPA). The purpose of this study is to improve student learning outcomes by using science class III teaching aids at MI Islamiyah Golantepus so that the output of student learning outcomes can be achieved. The research subjects were 27 students, the source of the research data was obtained from qualitative data in the form of observations of teacher and student activities and quantitative data in the form of student learning outcomes test data. The calculation results show that in the first cycle obtained by students who completed individually as many as 13 students from 27 students with classical completeness of $36 \%$ and classical absorption of $63 \%$. While the calculation results show that the second cycle has increased with the number of students who completed individually as many as 23 students out of 22 students who took part in learning with a classical percentage of completeness of $82 \%$ with a classical absorption of $85 \%$. Based on the results of calculations and analysis, learning to use science tools can improve the learning outcomes of third grade students at MI Islamiyah Golantepus, Mejobo Kudus District.
\end{abstract}

Keywords: Science Aids, Teachers, Learning Outcomes, Learning Process, Students

\section{PENDAHULUAN}

Perkembangan ilmu pengetahuan dan teknologi, serta dan globalisasi perlu dibarengi peningkatan sumber daya manusia. kebijakan yang ditempuh pemerintah dalam meningkatkan kualitas sumber daya manusia tersebut adalah pembaharuandalam bidang pendidikan, 
diantaranyaadalah model pembelajaran dari yang sifat konvensional kearah model pembelajaran yang efektif dan menyenangkan peserta didik. Peningkatan mutu pendidikan sebagai suatu kebutuhan bangsa yang ingin maju, dengan keyakinan penuh bahwa pendidikan yang bermutu dapat menunjang mutu di segala bidang. Oleh karena itu, pendidikan perlu mendapat perhatian yang besar agar kita dapat mengejar ketinggalan dibidang lmu pengetahuan dan teknologi yang mutlak kita perlukan untuk mempercepat pembangunan., Pendidikan yang bermutu perlu mendapat perhatian yang serius dari pemerintah. Guru memegang peranan strategis terutama dalam upaya membentuk watak bangsa melalui pengembangan kepribadian dan nilai-nilai yang diinginkan. Dari dimensi tersebut, peran guru sulit digantikan oleh yang lain.

Dalam pembelajaran Ilmu Pengetahuan Alam (IPA) di Sekolah Dasar (SD), agar bahan pengajaran yang di sampaikan menjadi lebih mudah di pahami oleh murid, di perlukan alat bantu pembelajaran juga pemilihan strategi, pendekatan, metode, dan teknik pembelajran yang menarik dan tepat dapat membantu penulis dan murid dalam mencapai tujuan pembelajaran (Karim, 2017)

Penggunaan alat peraga IPA adalah bentuk pembelajaran yang mengintegrasikan pemahaman dan penggunaan sains ke dalam rangkaian proses belajar mengajar guna mengarahkan siswa pada proses pengetahuan secara mandiri. Pelaksanaan pembelajaran IPA di kelas III pada sekolah dasar dengan menggunakan alat peraga IPA lebih menekankan pada pemberian pengalaman belajar secara langsung melalui percobaan, pengembangan keterampilan proses dan sikap ilmiah. Namun fenomena yang terjadi dalam pembelajaran IPA di kelas III MI Islamiyah Golantepus Mejobo Kudus belum memuaskan dengan Kriteria Ketuntasan Minimal (KKM) sebesar 70. Siswa yang mencapai KKM hanya 15 siswa dari 27 siswa artinya ketuntasan belajar siswa baru mencapai $36 \%$, sedangkan ketuntasan yang diharapkan adalah 63\%. Berarti proses pembelajaran yang dilaksanakan belum berhasil. Hal tersebut salah satunya disebabkan proses pembelajaran IPA yang dilakukan belum menggunakan alat peraga yang dapat memperjelas materi pelajaran.

Pembelajaran menggunakan alat peraga berarti mengoptimalkan fungsi seluruh panca indera siswa untuk meningkatkan efektivitas siswa belajar dengan cara mendengar, melihat, meraba, dan menggunakan pikirannya secara logis dan realistis(Alat, Boneka, Materi, \& Gajah, 2016). Berdasarkan penelitian yang dilakukan oleh Widiyatmoko (2013) menyatakan bahwa pembelajaran IPA yang menggunakan alat peraga lebih efektif dalam mencapai tujuan pembelajaran yang telah ditetapkan dibandingkan dengan tanpa menggunakan alat peraga. Alat peraga juga efektif meningkatkan hasil belajar siswa sesuai dengan penelitian yang dilakukan oleh Siswanto (2015). Selain itu menurut V.A.C Saputri, N. R. Dewi (2014) Penggunaan alat peraga dalam proses pembelajaran diharapkan dapat menumbuhkan keterampilan proses sains. Penelitian tentang alat peraga IPA dengan memanfaatkan bahan bekas pakai menunjukkan pemanfaatan bahan bekas pakai yang tersedia di lingkungan bisa dimaksimalkan sehingga dengan sendirinya mahasiswa akan terlatih dalam menjaga dan mengkonservasi lingkungan (Widiyatmoko \& Pamelasari, 2012)

Penggunaan alat peraga IPA dalam proses pembelajaran diharapkan dapat membantu kelancaran, efektif dan efesienpencapaian tujuan pembelajaran. Penggunaan alat peraga dalam pembelajaran terbukti lebih memudahkan siswa dalam memahami materi, sebab siswa merasa lebih senang dan tertarik dengan pembelajaran menggunakan alat peraga (Widiyatmoko \& Pamelasari, 2012) (Apriliyanti, Haryani, Widiyatmoko, \& Artikel, 2015) Alat/media dapat mempertinggi kualitas proses belajar siswa yang pada akhirnya akan mencapai hasil belajar yang diinginkan. Ada beberapa alasan mengapa alat peraga atau media dapat mempertinggi proses belajar siswa. Hal ini sesuai dengan pendapat Suherman dkk (2003) yang mengungkapkan bahwa dengan alat peraga/media akan diperoleh: Proses pembelajaran termotivasi, baik guru maupun siswa, minatnya akan timbul untuk belajar. (1) Rasa senang, terangsang dan tertarik terhadap proses pembelajaran; (2) Konsep abstrak tersajikan dalam bentuk kongkrit karena itu dapat dipahami dan di mengerti dan dapat ditanamkan pada tingkat-tingkat yang lebih rendah; (3) Hubungan antara konsep abstrak dengan benda-benda yang di alam sekitar lebih dapat dipahami;(4) Konsep-konsep abstrak dapat tersajikan dalam bentuk kongkrit yaitu dalam bentuk model;(5) Dalam proses pembelajaran akan lebih bermakna. Selain itu, (Anidityas, Utami, Widiyaningrum, \& Artikel, 2012) juga menyatakan bahwa pembelajaran 
menggunakan media pembelajaran berupa alat peraga dapat memperlihatkan berbagai aktivitas psikomotorik yang dilakukan oleh siswa. Menyadari dari pentingnya alat peraga/media pembelajaran dalam meningkatkan mutu pendidikan, guru dituntut untuk menguasai keterampilan memilih, mengembangkan dan menggunakan alat peraga/media yang sesuai dengan konsep yang dibahas/diajarkan.

Adapun tujuan yang ingin dicapai dalam penelitian ini adalah untuk meningkatkan hasil belajar siswa dengan menggunakan alat peraga IPA kelas III MI Islamiyah Golantepus Mejobo Kudus.

\section{METODE}

\section{Jenis Penelitian}

Jenis penelitian ini adalah penelitian tindakan kelas. Berdasarkan penjelasan Kemmis dan Mc Neiff tersebut, dapat dicermati pengertian PTK secara lebih rinci dan lengkap. PTK didefinisikan sebagai suatu bentuk kajian yang bersifat reflektif oleh pelaku tindakan.

Tindakan tersebut dilakukan untuk meningkatkan kemantapan rasional dari tindakan-tindakan mereka dalam melaksanakan tugas sehari-hari, memperdalam pemahaman terhadap tindakan-tindakan yang dilakukan, serta memperbaiki kondisi di mana praktik-praktik pembelajaran tersebut dilakukan. Untuk mewujudkan tujuan-tujuan tersebut, PTK dilaksanakan dalam proses berdaur (cyclical) yang terdiri dari empat tahapan, perencanaan, tindakan, observasi, evaluasi dan refleksi

\section{Desain Penelitian}

Penelitian ini merupakan penelitian tindakan kelas yang tiap tahapannya disebut siklus. Setiap siklus terdiri dari 4 kegiatan seperti yang dikemukakan oleh Kemmis dan Taggart (1993) dalam Nurbaya (2007) yaitu: 1) Rencana Siklus, 2) Tatap muka siklus, 3) Observasi dan 4) refleksi.

\section{Lokasi Penelitian}

Penelitian ini dilaksanakan di MI Islamiyah tahun pelajaran 2018-2019 dengan obyek penelitian siswa kelas III yang terdiri dari 19 orang laki-laki dan 8 orang perempuan yang terdaftar pada tahun pelajaran 2018/2019.

4. Waktu Penelitian

Penelitian ini dilaksanakan pada bulan September - Oktober 2018

a. Populasi

Populasi dari penelitian ini adalah seluruh siswa kelas III SD MI Islamiyah, dengan jumlah siswanya 27 Orang yang terdiri dari 19 orang laki-laki dan 8 orang perempuan.

b. Sampel

sebagian atau wakil populasi yang diteliti. Selanjutnya Arikunto (1998) memberikan penjelasan sebagai berikut : Apabila subyek kurang dari 100, lebih baik diambil semua sehingga penelitiannya merupakan penelitian populasi. Maka, jumlah sampel dalam penelitian ini adalah sejmlah 22 orang.

\section{Definisi Operasional Variabel}

Penelitian tindakan kelas ini direncanakan dua siklus, setiap siklus dilaksanakan sesuai dengan perubahan yang ingin dicapai. Kriteria keberhasilan tindakan dengan memperhatikan hasil belajar siswa secara individual dan klasikal.

1. Rencana Siklus I

Pada tahap ini peneliti menyusun perencanaan sebagai berikut

a. Menyiapkan RPP

b. Membuat Lembar Kerja Siswa

c. Membuat tes

d. Membuat lembar observasi aktivitas siswa untuk mengetahui kegiatan belajar siswa dan aktivitas guru.

2. Tatap Muka Siklus I

Pelaksanaan tindakan akan menggunakan alat peraga yang sesuai dengan rencana pelaksanaan pembelajaran.

Pendahuluan (5 menit) dengan aktivitas sebagai berikut :

a) Memberikan salam dan membaca doa

b) Memberikan apersepsi dan memotivasi peserta didik

c) Menuliskan judul dan tujuan pembelajaran Kegiatan Inti (50 menit ) dengan aktivitas berikut :

a. Kegiatan Guru

1) Membagi kelompok secara heteregon

2) Membagi Lembar Kerja Siswa (LKS) kepada siswa

3) Mengarahkan peserta didik untuk memperhatikan materi yang disampaikan

4) Menjelaskan materi pelajaran

5) Mengajukan pertanyaan yang bervariasi kepada peserta didik secara acak

b. Kegiatan peserta didik

1) Memperhatikan berbagai informasi yang disampaikan oleh guru

2) Berdiskusi menyatakan pendapat dalam kelompok atas pertanyaan yang diberikan 
3) Mengacungkan tangan untuk menjawab pertanyaan yang disampaikan oleh guru

c. Kegiatan penutup (15 menit) dengan aktivitas sebagai berikut :

1) Memberikan penguatan kepada siswa

2) Menyimpulkan materi pelajaran bersama dengan siswa berkaitan dengan materi yang telah diajarkan

3) Memberikan tes akhir secara individu untuk mengetahui tingkat pemahaman peserta didik

\section{Observasi Siklus I}

Kegiatan yang dilakukan pada tahap ini adalah mengobservasi dan mengevaluasi pelaksanaan tindakan. Kegiatan observasi ini mencakup aktivitas siswa dan aktivitas guru selama pelaksanaan tindakan siklus I.

Kriteria penilaian tiap aspek yang diobservasi ditentukan melalui pemberian skor. Indikator yang dinilai sangat baik oleh observer diberi skor 4, baik diberi skor 3, cukup diberi skor 2 , dan kurang diberi skor 1 . Selanjutnya untuk menganalisis data observasi digunakan persamaan persentase nilai rata-rata yaitu:

$$
\% \text { nilai rata-rata }=\frac{\text { Jumlah } \text { Skor }}{\text { skor maksimal }} \times 100 \%
$$

Kriteria taraf keberhasilan tindakan dapat ditentukan sebagai berikut:

$$
\begin{array}{lll}
90 \% & \leq \mathrm{NR} \leq 100 \% & =\text { Sangat baik } \\
80 \% & \leq \mathrm{NR} \leq 90 \% & =\text { Baik } \\
70 \% & \leq \mathrm{NR} \leq 80 \% & =\text { Cukup } \\
60 \% & \leq \mathrm{NR} \leq 70 \% & =\text { Kurang } \\
0 \% & \leq \mathrm{NR} \leq 60 \% & =\text { Sangat kurang }
\end{array}
$$

\section{Refleksi Siklus I}

Pada tahap ini adalah menganalisis data yang diperoleh pada tahap observasi. Berdasarkan analisis data dilakukan refleksi untuk melihat kekurangan 191 pada saat pembelajaran dilaksanakan. Kekurangan ini dijadikan acuan untuk merencanakan siklus selanjutnya.

\section{Rencana Revisi I Untuk Siklus II}

Berdasarkan hasil analisis tindakan yang dilaksanakan pada siklus I, dilakukan perbaikan pelaksanaan pembelajaran pada siklus II. Pelaksanaan tindakan penelitian siklus ke II ini disesuaikan dengan perubahan yang ingin dicapai. Hasil yang didapatkan dalam tahap ini dikumpulkan dan dianalisis. Hasil yang diperoleh digunakan untuk menyatakan apakah pembelajaran dilaksanakan dengan penggunaan alat peraga dapat meningkatkan hasil belajar siswa kelas III MI Islamiyah Golantepus Mejobo Kudus.

\section{Tatap Muka Siklus II}

Pelaksanaan tatap muka pada siklus II ini tidak jauh berbeda dengan pelaksanaan pada siklus I yang tahapannya meliputi:

Pelaksanaan pembelajaran akan menggunakan alat peraga yang sesuai dengan rencana pelaksanaan pembelajaran.

1. Pendahuluan (5 menit) dengan aktivitas sebagai berikut :

a. Memberikan salam dan membaca doa

b. Memberikan apersepsi dan memotivasi peserta didik

c. Menuliskan judul dan tujuan pembelajaran

2. Kegiatan Inti (50 menit) dengan aktivitas berikut :

a. Kegiatan Guru

1) Membagi kelompok secara heteregon

2) Membagi LKS kepada siswa

3) Mengarahkan peserta didik untuk memperhatikan materi yang disampaikan

4) Menjelaskan materi pelajaran

5) Mengajukan pertanyaan yang bervariasi kepada peserta didik

b. Kegiatan peserta didik

1) Memperhatikan berbagai informasi yang disampaikan oleh guru

2) Berdiskusi menyatakan pendapat dalam kelompok atas pertanyaan yang diberikan

3) Mengacungkan tangan untuk menjawab pertanyaan yang disampaikan oleh guru berkaitan dengan materi yang diajarkan

3. Kegiatan penutup (15 menit) dengan aktivitas sebagai berikut :

a. Memberikan penguatan kepada siswa

b. Menyimpulkan materi pelajaran bersama dengan siswa berkaitan dengan materi yang telah diajarkan

c. Memberikan tes akhir secara individu untuk mengetahui tingkat pemahaman peserta didik

\section{Observasi Siklus Ii}

Seperti halnya pada tindakan pada siklus I pada siklus II juga dilakukan observasi terhadap aktivitas guru dan siswa selama kegiatan pembelajaran yang dilakukan oleh observer.

\section{Refleksi Siklus Ii}

Setelah pemberian tindakan dilakukan refleksi berdasarkan tes akhir, lembar observasi, dan wawancara. Kegiatan yang dilakukan pada tahap ini adalah menganalisis data yang diperoleh 
dari hasil evaluasi, refleksi tindakan siklus II yang dilakukan untuk melihat apakah ada peningkatan hasil belajar dari siklus I ke siklus II.

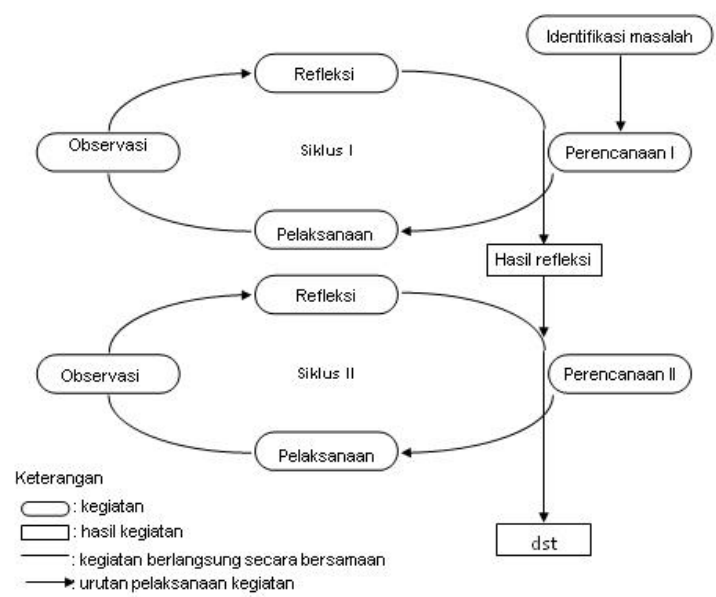

Gambar 1. Siklus PTK

\section{Jenis Dan Sumber Data}

Jenis data yang didapatkan dalam penelitian ini adalah data kualitatif dan data kuantitatif. Data kualitatif yaitu data yang diperoleh dari aktivitas siswa dan aktivitas guru berupa data hasil observasi dan hasil wawancara.

Data kuantitatif yaitu data yang diperoleh dari hasil tes yang diberikan kepada siswa.

\section{Teknik Pengumpulan Data}

Pengumpulan data dilakukan melalui tiga cara, yaitu :

1. Tes

Dilakukan untuk mengumpulkan informasi pemahaman siswa tentang materi yang diajarkan dengan menerapkan media kliping kliping. Tes terdiri dari tes awal dan tes akhir.

2. Observasi

Observasi dilakukan selama kegiatan pembelajaran berlangsung. Pelaksanaannya dilakukan dengan mengisi format yang telah disiapkan oleh peneliti dengan tujuan untuk mengetahui aktifitas dan perilaku subjek peneliti pada saat pembelajaran berlangsung.

\section{Instrumen Penelitian}

1. Validitas

Instrumen yang valid berarti alat ukur yang digunakan untuk mendapatkan data (mengukur) itu valid. Valid berarti instrument tersebut dapat digunakan untuk mengukur apa yang seharusnya diukur (Sugiyono, 2009).

2. Reliabilitas

Selain harus valid suatu instrument harus reliable (dapat diandalkan). Instrumen dikatakan reliabel atau handal jika alat ukur tersebut menghasilkan hasil-hasil yang konsisten. Dengan demikian instrument ini dapat dipakai dengan aman karena dapat bekerja dengan baik pada waktu berbeda dan dalam kondisi yang berbeda. Dengan kata lain reliabelitas menunjukan seberapa besar pengukuran dapat memberikan hasil yang relatif tidak berbeda, bila dilakukan pengukuran kembali terhadap subjek yang sama pada waktu yang berbeda dengan asumsi tidak terjadi perubahan psikologis pada responden.

\section{Teknik Analisa Data}

1. Kualitatif

Analisa data dalam penelitian ini dilakukan setelah pengumpulan data. Adapun tahap-tahap kegiatan analisis data kualitatif adalah a) mereduksi data, b) menyajikan data, dan c) penarikan kesimpulan dan verifikasi.

a. Mereduksi Data

Mereduksi data adalah proses kegiatan menyeleksi, memfokuskan, dan menyederhanakan semua data yang telah diperoleh, mulai dari awal pengumpulan data sampai penyusunan laporan penelitian.

b. Penyajian Data

Penyajian data dilakukan dalam rangka mengorganisasikan hasil reduksi dengan cara menyusun secara naratif sekumpulan informasi yang telah diperoleh dari hasil reduksi, sehingga dapat memberikan kemungkinan penarikan kesimpulan dan penarikan tindakan.

c. Penarikan Kesimpulan dan Verifikasi

Penarikan kesimpulan adalah proses penampilan intisari terhadap hasil penafsiran dan evaluasi. Kegiatan ini mencakup pencarian makna data serta memberi penjelasan. Selanjutnya dilakukan kegiatan verifikasi, yaitu menguji kebenaran, kekokohan, dan kecocokan makna-makna yang muncul dari data. Verifikasi data dimaksudkan untuk mengevaluasi segala informasi yang telah didapatkan suatu data yang diperoleh data dari informan, sehingga akan didapatkan suatu data yang validitas dan berkualitas serta hasil dari data tersebut dapat dipertanggung jawabkan kebenarannya. (Milles dan Hilberman, 1992).

\section{Teknik Analisa Data Kuantitatif}

Teknik analisa data yang digunakan dalam menganalisa data kuantitaif yang diperoleh dari hasil tes belajar siswa dan menentukan persentase ketuntasan belajar siswa dengan menggunakan rumus sebagai berikut: Daya Serap Individu.

Analisa data untuk mengetahui daya serap masing-masing siswa digunakan rumus sebagai berikut: 


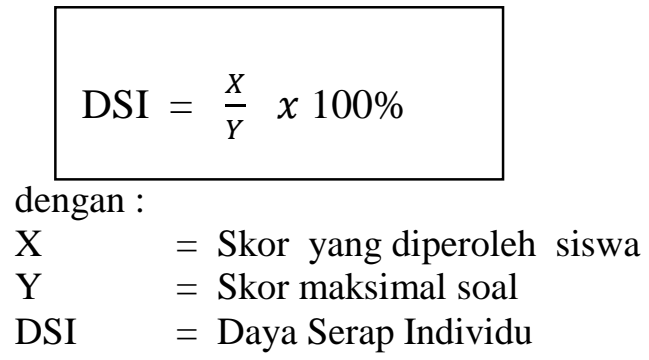

Suatu kelas dikatakan tuntas belajar secara individu jika persentase daya serap individu sekurang-kurangnya $70 \%$ (KKM SD Inpres 1 Siney).

\section{Ketuntasan Belajar Klasikal}

Analisa data untuk mengetahui ketuntasan belajar seluruh siswa yang menjadi sampel dalam penelitian ini, maka digunakan rumus sebagai berikut:

$$
\mathrm{KBK}=\frac{\Sigma N}{\Sigma S} \boldsymbol{x} 100 \%
$$

dengan :

$\sum N \quad=$ Banyaknya siswa yang tuntas

$\sum S \quad=$ Banyaknya siswa seluruhnya

KBK = Ketuntasan Belajar Klasikal

Suatu kelas dikatakan tuntas belajar klasikal jika rata-rata $85 \%$ pencapainanaya.

\section{Indikator Kinerja}

Penelitian ini dikatakan berhasil, jika hasil belajar siswa secara individu telah mencapai ketuntasan individu 70\% dan ketuntasan klasikal $85 \%$.

\section{HASIL DAN PEMBAHASAN}

\section{Siklus I}

a. Aktivitas Guru

Tabel 1. Hasil observasi aktivitas Guru Siklus I

\begin{tabular}{|l|l|c|c|}
\hline \multirow{2}{*}{ No } & \multicolumn{2}{|c|}{ Indikator yang diamati } & \multicolumn{2}{|c|}{ Pertemuan } \\
\cline { 2 - 4 } & $\begin{array}{l}\text { Kesiapan Guru memberikan } \\
\text { KBM }\end{array}$ & 3 & 4 \\
\hline 2 & Materi yang diajarkan & 2 & 3 \\
\hline 3 & Memotivasi Siswa & 2 & 3 \\
\hline 4 & $\begin{array}{l}\text { Menyiapkan indikator dan } \\
\text { tujuan pembelajaran }\end{array}$ & 3 & 3 \\
\hline 5 & $\begin{array}{l}\text { Menyampaikan materi } \\
\text { Pembelajaran menggunakan } \\
\text { alat peraga }\end{array}$ & 3 & 3 \\
\hline 6 & $\begin{array}{l}\text { Membagi siswa dalam } \\
\text { kelompok belajar dan LKS }\end{array}$ & 4 & 4 \\
\hline 7 & $\begin{array}{l}\text { Mengajaksiswa Melakukan } \\
\text { percobaan menggunakan alat } \\
\text { peraga }\end{array}$ & 3 & 3 \\
\hline 8 & $\begin{array}{l}\text { Membimbing siswa dalam } \\
\text { mengerjakan LKS }\end{array}$ & 2 & 3 \\
\hline
\end{tabular}

\begin{tabular}{|c|c|c|c|}
\hline 9 & $\begin{array}{l}\text { Melibatkan siswa pada saat } \\
\text { melakukan percobaan }\end{array}$ & 2 & 3 \\
\hline 10 & $\begin{array}{l}\text { Membimbing siswa dalam } \\
\text { menyelesaikan LKS }\end{array}$ & 2 & 3 \\
\hline 11 & $\begin{array}{l}\text { Membimbing siswa untuk } \\
\text { menyimpulkan materi }\end{array}$ & 2 & 3 \\
\hline 12 & Memberikan evaluasi & 3 & 4 \\
\hline & $\begin{array}{c}\text { Jumlah skor } \\
\text { Skor maksimal }\end{array}$ & $\begin{array}{l}31 \\
48\end{array}$ & $\begin{array}{l}39 \\
48\end{array}$ \\
\hline & Presentase (\%) & $65 \%$ & $81 \%$ \\
\hline
\end{tabular}

b. Aktivitas Sis Aktivitas Siswa

Tabel 2. Tabel Observasi Siklus I

\begin{tabular}{|c|c|c|c|}
\hline \multirow{2}{*}{ No } & \multirow{2}{*}{ Indikator yang diamati } & \multicolumn{2}{|c|}{ Pertemuan } \\
\hline & & 1 & 2 \\
\hline 1 & $\begin{array}{lcc}\text { Kesiapan siswa } & \text { dalam } \\
\text { mengikuti KBM } & \\
\end{array}$ & 4 & 4 \\
\hline 2 & $\begin{array}{lr}\text { Memberikan } & \text { tanggapan } \\
\text { terhadap } \\
\text { diberikan }\end{array}$ materi $\begin{array}{r}\text { yang } \\
\end{array}$ & 2 & 2 \\
\hline 3 & $\begin{array}{l}\text { Memperhatikan materi } \\
\text { pelajaran yang disampaikan } \\
\text { oleh Guru }\end{array}$ & 2 & 3 \\
\hline 4 & $\begin{array}{l}\text { Membentuk kelompok dan } \\
\text { membagi LKS }\end{array}$ & 3 & 3 \\
\hline 5 & $\begin{array}{l}\text { Melakukan percobaan } \\
\text { dengan menggunakan alat } \\
\text { peraga }\end{array}$ & 2 & 3 \\
\hline 6 & Bekerja secara kooperatif & 2 & 3 \\
\hline 7 & $\begin{array}{l}\text { Mengajukan pertanyaan atau } \\
\text { tanggapan }\end{array}$ & 2 & 2 \\
\hline 8 & 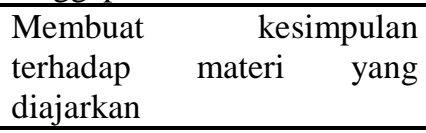 & 2 & 3 \\
\hline 9 & $\begin{array}{l}\text { Mengerjakan tes analisis } \\
\text { yang diberikan oleh guru }\end{array}$ & 3 & 4 \\
\hline & Jumlah sko & 22 & 27 \\
\hline & Skor maksima & 36 & 36 \\
\hline & Presentase (\%) & $61 \%$ & $75 \%$ \\
\hline
\end{tabular}

c. Hasil Belajar Siswa

Tabel 3. Hasil analisis tes akhir tindakan Siklus I

\begin{tabular}{|c|l|c|}
\hline No & Aspek yang diamati & Hasil \\
\hline 1 & Skor tertinggi & 92 \\
\hline 2 & Skor terendah & 54 \\
\hline 3 & Jumlah Siswa keseluruhan & 22 \\
\hline 4 & Banyaknya siswa yang tuntas & 8 \\
\hline 5 & Banyaknya siswa yang tidak tuntas & 14 \\
\hline 6 & Tuntas klasikal & $36 \%$ \\
\hline 7 & Daya Serap Klasikal & $68 \%$ \\
\hline
\end{tabular}


Siklus II

a. Aktivitas Guru

Tabel 4. Hasil observasi aktivitas Guru Siklus II

\begin{tabular}{|l|l|c|c|}
\hline \multirow{2}{*}{ No } & \multicolumn{2}{|c|}{ Indikator yang diamati } & \multicolumn{2}{|c|}{ Pertemuan } \\
\cline { 2 - 4 } & $\begin{array}{l}\text { Kesiapan Guru memberikan } \\
\text { KBM }\end{array}$ & 4 & 4 \\
\hline 2 & Materi yang diajarkan & 3 & 4 \\
\hline 3 & Memotivasi Siswa & 3 & 4 \\
\hline 4 & $\begin{array}{l}\text { Menyiapkan indikator dan } \\
\text { tujuan pembelajaran }\end{array}$ & 4 & 4 \\
\hline 5 & $\begin{array}{l}\text { Menyampaikan materi } \\
\text { Pembelajaran } \\
\text { menggunakan alat peraga }\end{array}$ & 4 & 4 \\
\hline 6 & $\begin{array}{l}\text { Membagi siswa dalam } \\
\text { kelompok belajar dan LKS }\end{array}$ & 4 & 4 \\
\hline 7 & $\begin{array}{l}\text { Mengajaksiswa Melakukan } \\
\text { percobaan menggunakan } \\
\text { alat peraga }\end{array}$ & 3 & 4 \\
\hline 8 & $\begin{array}{l}\text { Membimbing siswa dalam } \\
\text { mengerjakan LKS }\end{array}$ & 3 & 4 \\
\hline 9 & $\begin{array}{l}\text { Melibatkan siswa pada saat } \\
\text { melakukan percobaan }\end{array}$ & 3 & 4 \\
\hline 10 & $\begin{array}{l}\text { Membimbing siswa dalam } \\
\text { menyelesaikan LKS }\end{array}$ & 3 & 4 \\
\hline 11 & $\begin{array}{l}\text { Membimbing siswa untuk } \\
\text { menyimpulkan materi }\end{array}$ & 3 & 4 \\
\hline 12 & Memberikan evaluasi maksimal & 3 & 4 \\
\hline & $\begin{array}{l}\text { Presentase ( \%) } \\
\text { Membor }\end{array}$ & 48 \\
\hline
\end{tabular}

b. Aktivitas Siswa

Tabel 5. Tabel Observasi Siklus II

\begin{tabular}{|c|l|c|c|}
\hline \multirow{2}{*}{ No } & \multicolumn{2}{|c|}{ Indikator yang diamati } & \multicolumn{2}{|c|}{ Pertemuan } \\
\cline { 2 - 4 } 2 & $\begin{array}{l}\text { Kesiapan siswa dalam } \\
\text { mengikuti KBM }\end{array}$ & 4 & 4 \\
\hline 2 & $\begin{array}{l}\text { Memberikan tanggapan } \\
\text { terhadap materi yang } \\
\text { diberikan }\end{array}$ & 2 & 3 \\
\hline 3 & $\begin{array}{l}\text { Memperhatikan materi } \\
\text { pelajaran yang disampaikan } \\
\text { oleh Guru }\end{array}$ & 3 & 4 \\
\hline 4 & $\begin{array}{l}\text { Membentuk kelompok dan } \\
\text { membagi LKS }\end{array}$ & 4 & 4 \\
\hline 5 & $\begin{array}{l}\text { Melakukan percobaan } \\
\text { dengan menggunakan alat } \\
\text { peraga }\end{array}$ & 3 & 4 \\
\hline 6 & $\begin{array}{l}\text { Bekerja secara kooperatif } \\
\text { Mengajukan pertanyaan atau } \\
\text { tanggapan kesimpulan }\end{array}$ & 2 & 4 \\
\hline 8 & $\begin{array}{l}\text { Membuat yang } \\
\text { terhadap materi } \\
\text { diajarkan analisis }\end{array}$ & 2 & 3 \\
\hline 9 & $\begin{array}{l}\text { Mengerjakan tes ang diberikan oleh guru } \\
\text { yang }\end{array}$ & 4 & 4 \\
\hline
\end{tabular}

\begin{tabular}{|c|c|c|}
\hline Jumlah skor & 27 & 33 \\
Skor maksimal & 36 & 36 \\
Presentase (\%) & $75 \%$ & $92 \%$ \\
\hline
\end{tabular}

c. Hasil Belajar Siswa

Tabel 6. Hasil analisis tes Akhir Siklus II

\begin{tabular}{|c|l|c|}
\hline No & Aspek yang diamati & Hasil \\
\hline 1 & Skor tertinggi & 100 \\
\hline 2 & Skor terendah & 40 \\
\hline 3 & Jumlah Siswa keseluruhan & 22 \\
\hline 4 & Banyaknya siswa yang tuntas & 18 \\
\hline 5 & Banyaknya siswa yang tidak tuntas & 4 \\
\hline 6 & Tuntas klasikal & $82 \%$ \\
\hline 7 & Daya Serap Klasikal & $85 \%$ \\
\hline
\end{tabular}

Penggunaan alat peraga dalam pembelajaran IPA dapat meningkatkan hasil belajar siswa kelas III di MI Islamiyah Golantepus Mejobo Kudus. Hal ini terlihat dari ketuntasan belajar siswa secara klasikal yang mengalami peningkatan dari Siklus I ke Siklus II sebesar $46 \%$, peningkatan hasil belajar tersebut juga di tunjang oleh aktivitas guru dan siswa selama proses belajar mengajar. Hal ini sesuai dengan penelitian Nurfa (2012) yang menyatakan bahwa penggunaan alat peraga sistem pernapasan manusia dapat meningkatkan keaktifan siswa, motivasi dan hasil belajar siswa Sekolah Menengah Pertama (SMP) kelas VIII.

Berdasarkan hasil observasi aktivitas guru pada siklus I terhadap kegiatan pembelajaran, aktivitas guru mengalami meningkatan dari $65 \%$ pada pertemuan pertama dan $81 \%$ pada pertemuan kedua. Peningkatan tersebut menunjukan bahwa aktivitas guru berada dalam kategori baik, tetapi dalam pelaksanaan pembelajaran belum terpenuhinya semua indikator yang diamati pada setiap pertemuan, oleh karena itu perlu diadakan perbaikanperbaikan sehingga aktivitas guru berada dalam ketegori baik atau sangat baik. Sedangkan hasil observasi aktivitas siswa terhadap kegiatan pembelajaran berada dalam kategori cukup yaitu $61 \%$ pada pertemuan pertama dan $75 \%$ pada pertemuan kedua. Hal ini disebabkan karena Siklus I guru lebih banyak mendominasi pada saat kegiatan diskusi dengan menggunakan alat peraga sehingga siswa hanya sebagai pendengar dan tidak terlibat secara aktif dalam kegiatan tersebut sebab siswa belum termotivasi dalam memberikan tanggapan pada saat kegiatan diskusi berlangsung. 
Hasil tes tindakan Siklus I menunjukan bahwa ketuntasan belajar klasikal diperoleh sebesar $36 \%$ sehingga belum mencapai indikator yang ditetapkan yaitu sebesar $85 \%$ sedangkan daya serap klasikalnya $63 \%$ dan belum mencapai indikator yang ditetapkan yaitu $65 \%$. Siswa yang tuntas belajar sebanyak 13 orang dan tidak tuntas sebanyak 17 orang. Hal ini disebabkan karena sebagian siswa

belum termotivasi dalam dan memahami konsep yang diajarkan dengan menggunakan alat peraga.

Berdasarkan hasil observasi siswa dan Guru serta hasil tes akhir tindakan di atas maka peneliti melaksanakan Siklus II agar proses pembelajaran dengan menggunakan alat peraga ini lebih efektif dan efesien, guru berusaha untuk meminimalkan kekurangan yang terdapat di Siklus I dengan melakukan refleksi. Guru berusaha untuk memotivasi siswa supaya lebih aktif dan antusias dalam mengikuti proses pembelajaran dan memberikan bimbingan agar siswa lebih berani dalam mengemukakan pendapatnya dan memberikan waktu yang cukup untuk siswa dalam memberikan tanggapannya agar siswa dapat terlibat aktif dalam proses pembelajaran.

Berdasarkan hasil observasi aktivitas Guru dan siswa pada Siklus II, yaitu aktivitas Guru pada pertemuan pertama diperoleh $83 \%$ dan pertemuan kedua $100 \%$ sedangkan aktivitas siswa pada pertemuan pertama diperoleh $72 \%$ dan pertemuan kedua $92 \%$ dalam proses pembelajaran berada dalam kategori sangat baik ditunjukan dengan terlaksananya hampir keseluruhan indikator yang diamati pada setiap pertemuan pada proses pembelajaran. Guru sudah mampu membimbing dan memotovasi siswa dalam pembelajaran serta memberikan waktu yang cukup untuk siswa dalam mengemukakan pendapatnya.

Siswa sangat antusias dalam proses pembelajaran hal tersebut ditunjukan dengan cara siswa terlibat langsung dan aktif dalam kegiatan pembelajaran dengan menggunakan alat peraga. Siswa sangat antusias untuk melakukan percobaan dengan menggunakan alat peraga.

Antusias siswa tersebut berdampak positif pada hasil belajar mereka, hal tersebut dapat dilihat pada hasil tes akhir tindakan Siklus II. Ketuntasan belajar klasikal yang dicapai siswa sebesar $82 \%$ dan daya serap klasikalnya $85 \%$. Hasil belajar klasikal dengan menggunakan alat peraga pada Siklus II lebih efektif. Hal ini terlihat dari tercapainya indikator keberhasilan yang diharapkan, dikarenakan pembelajaran dengan alat peraga dapat menciptakan suasana pembelajaran yang menyenangkan terlihat dari banyaknya siswa yang antusias dan terlibat langsung dalam kegiatan pembelajaran.

Peningkatan hasil belajar dengan menggunakan alat peraga terlihat sangat jelas pada Siklus I dan Siklus II. Ketuntasan belajar Klasikalnya pada Siklus I sebesar 36\% dengan daya serap klasikalnya $68 \%$, sedangkan pada Siklus II ketuntasan belajar klasikalnya $82 \%$ dengan daya serap klasikalnya 85 . Peningkatan hasil belajar siswa secara klasikal dari Siklus I ke Siklus II sebesar $49 \%$ Sedangkan peningkatan daya serap secara klasikalnya dari Siklus I ke Siklus II sebesar $17 \%$. Hal tersebut menunjukan bahwa pembelajaran dengan menggunakan alat peraga dinyatakan berhasil.

Penggunaan alat peraga pada proses pembelajaran menempatkan siswa menjadi subjek pembelajaran (Student Centered Learning sebagai objek pembelajaran sehingga pembelajaran tidak hanya di dominasi oleh guru tetapi memberikan kesempatan kepada siswa agar untuk terlibat langsung dalam kegiatan tersebut. Serta dapat menimbulkan rasa kekeluargaan dan kebersamaan antar siswa sehingga siswa dapat bersosialisasi dengan temannya pada saat proses pembelajaran berlangsung.

\section{SIMPULAN}

Berdasarkan hasil analisis data yang diperoleh selama pelaksanaan tindakan Siklus I dan Siklus II maka dapat disimpulkan bahwa penggunaan alat peraga pada Mata Pelajaran IPA dengan pokok bahasan gaya dapat meningkatkan hasil belajar siswa kelas III di MI Islamiyah tahun pelajran 2018 - 2019. Hal ini dapat dilihat dari analisis data selama pelaksanaan tindakan Siklus I dan Siklus II. Pada Siklus I ketuntasan belajar siswa secara klasikal sebesar 36\% dengan daya serap klasikalnya sebesar $68 \%$. Sedangkan pada siklus II ketuntasan belajar siswa secara klasikal sebesar $82 \%$ dengan daya serap klasikalnya sebesar $85 \%$.Peningkatan ketuntasan klasikal dari siklus I ke Siklus II sebesar 46\% sedangkan peningkatan daya serap klasikal dari siklus I ke siklus II sebesar $17 \%$.. 


\section{DAFTAR PUSTAKA}

Alat, P., Boneka, P., Materi, E., \& Gajah, N. (2016). Pengembangan Alat Peraga Boneka Edukatif Materi Sistem Organisasi Kehidupan pada Siswa Kelas VII MTs Negeri GAJAH ItsnaUnnes Science Education Journal. Unnes Science Education Journal, 5(1), 1175-1181.

Anidityas, N. A., Utami, N. R., Widiyaningrum, P., \& Artikel, I. (2012). Penggunaan Alat Peraga Sistem Pernafasan Manusia Pada Kualitas Belaar Siswa SMP Kelas VIII. /journal.unnes.ac.id/sju/index.php/usej, $1(2)$.

Apriliyanti, D. D., Haryani, S., Widiyatmoko, A., \& Artikel, I. (2015). Pengembangan Alat Peraga IPA Terpadu Pada Tema Pemisahan. Unnes Science Education Journal, 4(2).

Karim, A. (2017). Upaya peningkatan Hasil Belajar IPA Tentang Membiasakan Hidup Sehat Dengan Menggunakan Alat Peraga dan Menumbuhkan Sikap Disiplin Pada Murid Kelas I SD ISLAM NU PUNGKURAN 2016 / 2017. Seminar Nasional Pendidikan, Sains Dan Teknologi Fakultas Matematika Dan Ilmu Pengetahuan Alam Universitas Muhammadiyah Semarang.

Widiyatmoko, A., \& Pamelasari, S. D. (2012). Pembelajaran Berbasis Proyek Untuk Mengembangkan Alat Peraga IPA Dengan Memanfaatkan Bahan Bekas Pakai. Jurnal Pendidikan IPA Indonesia, 1(1), 51-56.

$$
\begin{aligned}
& \text { Arikunto. (1998). Metodologi } \\
& \text { Penelitian. [on-line] } \\
& \text { Tersedia: }
\end{aligned}
$$

belajarstatistik.wordpress.com/2008/09/28/met odologi-penelitian [ 1 Oktober 2018]
Depdiknas. (2003). Kurikulum 2004, Standar Kompetensi Mata Pelajaran Sains Sekolah Dasar dan MI. Jakarta: Depdiknas.

Kharitsa, Itsna Syafi' dkk, Pengembangan Alat Peraga Boneka Edukatif Materi Sistem Organisasi Kehidupan Pada Siswa Kelas VII MTs Negeri Gajah, Unnes Science Education Journal , 5 (1) (2016): 11751181

Kualitatif. Bandung: Alfa Beta

Milles dan Hilberman. (1992). Analisis Data Kualitatif Terjemahan Rohendi Rohidi. Jakarta: Universitas Indonesia

Nurbaya. (2007). Penerapan Teknik Simulasi Dalam Matra Kognitif Untuk Meningkatkan Hasil Belajar Fisika Siswa Kelas VII Otomotif A SMP Negeri 15 Palu. Skripsi Sarjana Pada Fakultas Keguruan dan Ilmu Pendidikan Universitas Tadulako: Tidak diterbitkan

Saputri, V. A. C. dan N. R. Dewi, Pengembangan Alat Peraga Sederhana Eye Lens Tema Mata Kelas Viii Untuk Menumbuhkan Keterampilan Peserta Didik, Jurnal Pendidikan IPA Indonesia, JPII 3 (2) (2014) 109-115

Siswanto, Meningkatkan Hasil Belajar Ipa Dengan Menggunakan Alat Peraga Organ Tubuh Manusia (Torso) Pada Siswa Kelas V SDN Manggisan 01 Tanggul Kabupaten Jember, Pancaran, Vol. 4, No. 1 (2015), hal $129-140$

Sudjana Nana dan Rivai Ahmad. (2001). Faktorfaktor yang mempengaruhi hasil belajar [online]

TersediaHttp://harminingsih.blogspot.com /2008/08/faktor-faktor yang mempengaruhi hasil belajar.html [2 Maret 2014] 
Sugiyono. (2007). Metode Penelitian

Pendididikan Pendekatan

Kuantitatif

Suherman, dkk. (2007). Strategi Pembelajaran Matematika Kontemporer. Bandung: JICA

Sulistyoningsih, Abdul Karim, Upaya Meningkatkan Hasil Belajar Ipa Tentang Membiasakan Hidup Sehat Dengan
Menggunakan Alat Peraga Dan Menumbuhkan Sikap Disiplin Pada Murid Kelas I SD Islam $\mathrm{Nu}$ Pungkuran 2016/2017

\section{PROFIL SINGKAT}

Mahfud merupakan mahasiswa Pasca Sarjana PGMI, IAIN Salatiga Jl.Lingkar Salatiga Indonesia dan Mahfud Nahrowi merupakan Alumni STAIN Kudus, Anggota Forkapisa IAIN Salatiga 